\title{
Determinants of glycemic control in female diabetic patients: a study from Iran
}

\author{
Zeinab Ghazanfari', Shamsaddin Niknami ${ }^{1 *}$, Fazlollah Ghofranipour ${ }^{1}$, Bagher Larijani ${ }^{2}$, Hamid Agha-Alinejad ${ }^{3}$, \\ Ali Montazeri $^{4}$
}

\begin{abstract}
Background: Since microvascular and macrovascular complications are reduced through strict glycemic control, this study carried out to identify the factors that affect glycemic control.

Methods: A cross-sectional design was carried out to examine the role of demographic, anthropometric, clinical and other relevant characteristics in a sample of 103 female diabetic patients in Tehran, Iran. Personal interviews were conducted to collect data. Then blood sampling collected and the patients were divided into two outcome groups (controlled and uncontrolled diabetes). The groups were compared on the basis of their characteristics using both univariate and multivariate analyses.

Results: In all 103 patients were entered into the study. The mean age of patients was 46.38 (SD = 11.42) years. Overall, the mean value of HbA1c for the whole sample was 7.5 (SD = 2.35) and 56.3\% had HbA1c $\geq 7 \%$. The findings obtained from univariate analysis revealed that there were no significant differences between controlled and uncontrolled patients. However, in multivariate analysis the waist circumference was found to be a significant predictor of increased level of $\mathrm{HbA1c}(\mathrm{OR}=1.04,95 \% \mathrm{Cl}=1-1.08, \mathrm{P}=0.04)$.

Conclusions: The findings suggest that increased level of $\mathrm{HbA} 1 \mathrm{C}$ is associated with waist circumference that is a modifiable factor. It seems that physical activity might be a solution to overcome this health problem. A larger study to identify other factors also is recommended.
\end{abstract}

\section{Background}

Glycemic control is essential in diabetes management [1]. Since lower level of blood glucose leads to decreased rates of morbidity and mortality, maintaining glycemic control is a goal for all patients with diabetes [2]. Prospective randomized clinical trials and epidemiological studies have shown that glycemic control is related with reduced rates of retinopathy, nephropathy, neuropathy and cardiovascular diseases [1-3]. Glycemic control is considered as the main therapeutic goal for prevention of organ damage and other complications of diabetes [4].

Glycosylated hemoglobin $\left(\mathrm{HbA}_{1 \mathrm{C}}\right)$ is the primary target of glycemic control. In this regard, desirable value for $\mathrm{HbA}_{1 \mathrm{C}}$ is values below 7 [2,3]. HbA1c is a gold standard in analysis of patients' status, and is essential to

\footnotetext{
* Correspondence: niknamis@modares.ac.ir

'Department of Health Education, Tarbiat Modares University, Tehran, Iran Full list of author information is available at the end of the article
}

ensure the optimal care of diabetic patients [5]. $\mathrm{HbA}_{1 \mathrm{C}}$ is the index that indicates the average blood glucose during the past 3 months. One percent change in $\mathrm{HbgA}_{1 \mathrm{C}}$ is equivalent to an approximately $35 \mathrm{mg} / \mathrm{dl}$ change in mean plasma glucose $[2,6]$. Smaller values of $\mathrm{HbA}_{1 \mathrm{C}}$ indicate better glycemic control [7]. The research has shown that with each one percent reduction in the value of $\mathrm{HbA} 1 \mathrm{C}$, the risk of microvascular complications is reduced by 40 percent [2].

Despite evidences that strict glycemic control could reduce microvascular and macrovascular complications [8-10], a high proportion of patients remain poorly controlled [11]. Achieving optimal glycemic control in clinical practice is difficult and the reasons for its poor control are complex. A variety of factors are identified in influencing glycemic control including age, sex, education, marital status, BMI, smoking, diabetes duration, and type of medications [4,12-14]. However, the results are not consistent and in most instances more than half of the variance in $\mathrm{HbA1c}$ changes are not explained
C Biomed Central

(c) 2010 Ghazanfari et al; licensee BioMed Central Ltd. This is an Open Access article distributed under the terms of the Creative Commons Attribution License (http://creativecommons.org/licenses/by/2.0), which permits unrestricted use, distribution, and reproduction in any medium, provided the original work is properly cited. 
[13]. Thus, the current study aimed to examine these factors in Iran, where there are no information on the topic. We thought this might contribute to existing knowledge and help to enhance women's health.

\section{Methods}

\section{Design and data collection}

A cross-sectional study was carried out to examine the role of demographic, anthropometric, clinical and other relevant characteristics in glycemic control among women attending a diabetes clinic affiliated to the Charity Foundation for Special Diseases (CFFSD), in Tehran, Iran between November 2008 and July 2009. The inclusion criteria were: aged between 15 to 70 years, being literate, no history of diabetes complications, and mental and disabling disorders. To collect data, trained interviewers carried out face-to-face interviews.

\section{Measures}

1. Demographic information: this included data on age, education, marital status, smoking, duration of disease, and family history of diabetes mellitus

2. Anthropometrics data: this included information on body mass index (BMI), and waist and hip circumference. Trained research personnel measured height and weight by a Seca 220 (made by Germany) while the subjects were minimally clothed and not wearing Shoes. The body mass index was calculated based on heights and weights $\left[\mathrm{BMI}=\right.$ weight $\left.(\mathrm{kg}) /(\text { height }(\mathrm{m}))^{2}\right]$. Based on the BMI, women were grouped into different categories as recommended by the WHO: normal range $(\mathrm{BMI}=$ $\left.18.5-24.9 \mathrm{~kg} / \mathrm{m}^{2}\right)$, overweight $\left(\mathrm{BMI}=25-29.9 \mathrm{~kg} / \mathrm{m}^{2}\right)$, and obese $\left(\mathrm{BMI} \geq 30 \mathrm{~kg} / \mathrm{m}^{2}\right)$ [15].

Waist and hip circumference were measured in centimeters using a plastic tape meter at the level of the umbilicus and of the greater trochanters.

3. Clinical measures: this included data on glycosylated hemoglobin $\left(\mathrm{HbA}_{1 \mathrm{C}}\right)$, systolic and diastolic blood pressure, the presence of dislipidemia, and medication. Glycosylated hemoglobin was analyzed using immunoturbidometric assay [16]. Blood pressure was measured with a mercury sphygmomanometer in a sitting position after 5 minutes rest.

4. Other relevant data: this included information on self-monitoring blood glucose (SMBG).

\section{Statistical analysis}

Patients were divided into two groups for comparison: (1) controlled: the HbA1c level less than 7\%, (2) uncontrolled: the HbA1c level equal or greater than $7 \%[2,3]$. Both univariate and multiple logistic regression analyses were used to indicate the association between dependent (controlled vs. uncontrolled diabetes) and independent variables. Independent variables tested for an association were age, education, marital status, smoking, body mass index, waist and hip circumferences, duration of disease, family history of diabetes mellitus, SMBG, medication type, systolic and diastolic blood pressure, and the presence of dislipidemia.

\section{Ethics}

The Ethics Committee of Tarbiat Modares University approved the study. Written informed consent was obtained from participants after comprehensive explanation of the procedure involved.

\section{Results}

In all, 103 patients were entered into the study (45 controlled and 58 uncontrolled diabetes). The mean age of participants was 46.38 (SD = 11.42), and ranged from 15 to 68 years. The mean for BMI and duration of disease were 27.7 ( $\mathrm{SD}=5.04)$, and $8.55(\mathrm{SD}=6.10)$ respectively. Overall, the mean value of HbA1c for the whole sample was $7.5(\mathrm{SD}=2.35)$ and $56.3 \%$ had $\mathrm{HbA} 1 \mathrm{c} \geq 7 \%$. The characteristics of the study sample are presented in Table 1.

The results obtained from univariate logistic regression analysis indicated that there were no significant differences between controlled and uncontrolled patients. The results are shown in Table 1 . However, when forward conditional multiple logistic regression analysis was performed, the results showed that waist circumference emerged as a significant factor for increased level of HbA1c $(\mathrm{OR}=1.04,95 \% \mathrm{CI}=1-1.08, \mathrm{P}=0.04)$.

\section{Discussion}

This was the first study to examine the association between glycemic control and demographic, anthropometric, clinical and other relevant data in a sample of Iranian females with diabetes. Overall the proportion of patients with poor glycemic control was high (56.3\%), and controlled and uncontrolled patients did not differ significantly with respect to age, education, marital status, smoking, duration of disease, family history of diabetes mellitus, SMBG, medication, systolic and diastolic blood pressure, waist and hip circumferences and the presence of dislipidemia. However, the association between increased level of HbA1c and variables studied were in the expected directions (Table 1).

The results obtained from multivariate logistic regression analysis indicated that the differences between patients who gained control and those who did not were due to waist circumference $(O R=1.04)$. Similarly Yoshida and Okosun argued that physiologic factors are important in diabetes control where they have showed the association between glycemic control and waist circumference $[17,18]$. However, Hartz et al. suggested that patient factors such as understanding of diabetes and 
Table 1 The results obtained from univariate logistic regression analysis for increased level of $\mathrm{HbA1c}$

\begin{tabular}{|c|c|c|c|c|}
\hline & $\begin{array}{l}\text { Controlled diabetes }(n=45, \\
\text { HbA1c }<7)\end{array}$ & $\begin{array}{l}\text { Uncontrolled diabetes }(n=58, \\
H b A 1 c \geq 7)\end{array}$ & & \\
\hline & No (\%) & No (\%) & OR $(95 \% \mathrm{Cl})$ & P-value \\
\hline Age (year; Mean, SD) & $45.3(10.98)$ & $46.84(12.48)$ & $1.01(0.98-1.04)$ & 0.51 \\
\hline \multicolumn{5}{|l|}{ Education } \\
\hline Higher & $9(20)$ & $7(12.1)$ & 1.0 (ref.) & \\
\hline Secondary & $29(64.4)$ & $40(69)$ & $1.77(0.59-5.31)$ & 0.31 \\
\hline Primary & $7(15.6)$ & $11(19)$ & $2.02(0.51-7.94)$ & 0.31 \\
\hline \multicolumn{5}{|l|}{ Marital status } \\
\hline Married & $38(84.4)$ & $44(75.9)$ & 1.0 (ref.) & \\
\hline Single & $4(8.9)$ & $7(12.1)$ & $1.51(0.41-5.56)$ & 0.53 \\
\hline Widowed/divorced & $3(6.7)$ & $7(12.1)$ & $2.01(0.49-8.34)$ & 0.33 \\
\hline \multicolumn{5}{|l|}{ Smoking } \\
\hline$\overline{\text { No }}$ & $41(91.1)$ & $52(89.7)$ & 1.0 (ref.) & \\
\hline$\overline{Y e s}$ & $4(8.9)$ & $6(10.3)$ & $1.18(0.31-4.47)$ & 0.80 \\
\hline \multicolumn{5}{|l|}{ Body Mass Index $\left(\mathrm{kg} / \mathrm{m}^{2}\right)$} \\
\hline$<25$ & $19(43.2)$ & $16(27.6)$ & 1.0 (ref.) & \\
\hline $25-30$ & $15(34.1)$ & $22(37.9)$ & $1.74(0.68-4.43)$ & 0.24 \\
\hline$>30$ & $10(22.7)$ & $20(34.5)$ & $2.37(0.87-6.52)$ & 0.09 \\
\hline \multicolumn{5}{|l|}{ Family history of diabetes } \\
\hline$\overline{Y e s}$ & $36(80)$ & $44(75.9)$ & 1.0 (ref.) & \\
\hline$\overline{\text { No }}$ & $9(20)$ & $14(24.1)$ & $1.27(0.49-3.28)$ & 0.62 \\
\hline \multicolumn{5}{|l|}{ SMBG } \\
\hline Yes & $32(71.1)$ & $37(63.8)$ & 1.0 (ref.) & \\
\hline No & $13(28.9)$ & $21(36.2)$ & $1.40(0.60-3.23)$ & 0.43 \\
\hline \multicolumn{5}{|l|}{ Medication type } \\
\hline None & $4(8.9)$ & $1(1.7)$ & 1.0 (ref.) & \\
\hline Insulin alone & $10(22.2)$ & $6(10.3)$ & $2.40(0.21-26.82)$ & 0.47 \\
\hline Tablet and insulin & $5(11.1)$ & $7(12.1)$ & $5.60(0.47-66.45)$ & 0.17 \\
\hline Tablet alone & $26(57.8)$ & $44(75.9)$ & $6.77(0.72-63.86)$ & 0.09 \\
\hline \multicolumn{5}{|l|}{ Dislipidemia } \\
\hline No & $22(50)$ & $31(53.4)$ & 1.0 (ref.) & \\
\hline Yes & $22(50)$ & $27(46.6)$ & $0.87(0.40-1.91)$ & 0.73 \\
\hline $\begin{array}{l}\text { Duration of disease } \\
\text { (year; Mean, SD) }\end{array}$ & $8.66(6.49)$ & $8.76(5.74)$ & $1.003(0.94-1.07)$ & 0.93 \\
\hline $\begin{array}{l}\text { Systolic Blood pressure }(\mathrm{mmHg} \\
\text { Mean, SD) }\end{array}$ & $119.67(17.63)$ & $122.07(16.33)$ & $1.01(0.98-1.03)$ & 0.47 \\
\hline $\begin{array}{l}\text { Diastolic Blood pressure (mmHg; } \\
\text { Mean, SD) }\end{array}$ & $76.11(11.12)$ & 77.33 (8.39) & $1.01(0.97-1.06)$ & 0.52 \\
\hline $\begin{array}{l}\text { Waist circumference } \\
(\mathrm{Cm} ; \text { Mean, SD) }\end{array}$ & 85.52 (11.24) & $89.44(10.24)$ & $1.03(0.1-1.07)$ & 0.07 \\
\hline $\begin{array}{l}\text { Hip circumference } \\
(\mathrm{Cm} ; \text { Mean, SD) }\end{array}$ & $101.65(10.71)$ & $103.92(9.19)$ & $1.02(0.98-1.07)$ & 0.25 \\
\hline
\end{tabular}

Cl: Confidence Interval

adherence to recommended behaviors and not physiologic factors are primary important factors on gaining control over glycosylated hemoglobin [12].

Any modifiable factors that influence glycemic control could be important [19]. In present study waist circumference was a predictor of increased level of HbA1c and thus it is the only modifiable factor in this regard. Waist circumference is often used as a proxy measure of abdominal adipose tissue, in particular, visceral adipose tissue (VAT) in clinical settings. VAT has 
been reported to create a greater risk for developing obesity related disorders than subcutaneous adipose tissue (SAT) [20-23]. Obesity should be considered as a chronic disease with multi-factorial etiology, and treatment must be maintained for life-first with lifestyle interventions (energy-reduced diet and increased physical activity) and then with pharmacologic approaches, when necessary [24].

Although other studies found a significant relationship between age [25-27], BMI [26], smoking [26,28], duration of diabetes $[4,27,29]$, and HbA1c, this study did not show such associations. However, our findings on relationship between duration of diabetes, and medication and HbA1c level was similar to the findings by Goudswaard et al. and Hartz et al., respectively [13,12].

The findings from this study might be influenced by several limitations. The sample size was small making it difficult to generalize the findings. Secondly, patients were female and recruited from a single institute rather than being a community-based sample. Thus the findings could not be generalized beyond this study sample. Finally most measures in this study were self-reported and therefore the possibility of recall bias should not be neglected.

\section{Conclusions}

The findings suggest that increased level of HbA1c is associated with waist circumference that is a modifiable factor. It seems that physical activity might be a solution to overcome this health problem. A larger study to identify other factors also is recommended.

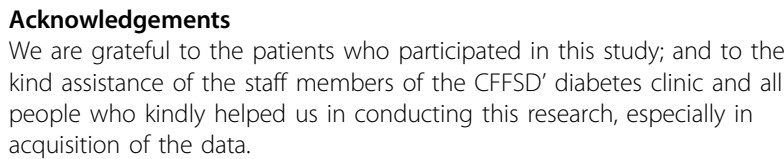
kind assistance of the staff members of the CFFSD' diabetes clinic and all people who kindly helped us in conducting this research, especially in acquisition of the data.

\section{Author details \\ ${ }^{1}$ Department of Health Education, Tarbiat Modares University, Tehran, Iran. ${ }^{2}$ Endocrine and Metabolism Research Center, Shariati Hospital, Tehran University of Medical Sciences, Tehran, Iran. ${ }^{3}$ Department of Exercise Physiology, Islamic Azad University, Central Tehran Branch, Tehran, Iran. ${ }^{4}$ Department of Mental Health, Institute for Health Sciences Research, ACECR Tehran, Iran. \\ Authors' contributions \\ ZGh was the main investigator, collected the data, performed the statistical analysis, and drafted the manuscript. SHN supervised the research and contributed to all aspects of the study. FGH was advisor of the study and contributed to design and study implementation. BL was advisor of the study and helped to recruit the patients. HAA helped in implementation of the study and interpretation of the data. AM helped as a consultant in study design, questionnaire, and revised the final article. All authors read and approved the final manuscript.}

\section{Competing interests}

The authors declare that they have no competing interests.

Received: 3 July 2010 Accepted: 11 August 2010

Published: 11 August 2010
References

1. Middleton J: The effect of case management on glycemic control in patients with type 2 diabetes. The Case Manager 2003, 14:43-47.

2. Bevan JL: Diabetes mellitus: a review of select ADA standards for 2006. J Nurse Pract 2006, 2:674-679.

3. American Diabetes Association: Standards of medical care in diabetes2009. Diabetes Care 2009, 32:S13-S61.

4. Khattab M, Khader YS, Al-Khawaldeh A, Ajlouni K: Factors associated with poor glycemic control among patients with type 2 diabetes. J Diabetes Complications 2003, 24:84-89.

5. Roszyk L, Faye B, Sapin V, Somda F, Tauveron I: Glycated haemoglobin (HbA1c): today and tomorrow. Ann Endocrinol(Paris) 2007, 68:357-365.

6. Alam T, Weintraub N, Weinreb J: What is the proper use of hemoglobin A1C monitoring in the elderly? J Am Med Dir Assoc 2006, 7:60-64.

7. Hsin O, La Greca AM, Valenzuela J, Moine CT, Delamater A: Adherence and glycemic control among Hispanic youth with type 1 diabetes: Role of family involvement and acculturation. J Pediatr Psychol 2010, 35:156-166.

8. Stratton IM, Adler Al, Neil HA, Matthews DR, Manley SE, Cull CA, Hadden D, Turner RC, Holman RR: Association of glycaemia with macrovascular and microvascular complications of type 2 diabetes (UKPDS 35): prospective observational study. BMJ 2000, 321:405-412.

9. Saaddine JB, Cadwell B, Gregg EW, Engelgau MM, Vinicor F, Imperatore G, Narayan KM: Improvements in diabetes processes of care and intermediate outcomes: United States, 1988-2002. Ann Intern Med 2006, 144:465-474.

10. UK Prospective Diabetes Study (UKPDS) Group: Intensive blood-glucose control with sulphonylureas or insulin compared with conventional treatment and risk of complications in patients with type 2 diabetes (UKPDS 33). Lancet 1998, 352:837-853.

11. Karter AJ, Moffet HH, Liu J, Parker MM, Ahmed AT, Ferrara A, Selby JV: Achieving good glycemic control: initiation of new antihyperglycemic therapies in patients with type 2 diabetes from the Kaiser Permanente Northern California Diabetes Registry. Am J Manag Care 2005, 11:262-270.

12. Hartz A, Kent $S$, James $P, X u Y$, Kelly M, Daly J: Factors that influence improvement for patients with poorly controlled type 2 diabetes. Diabetes Res Clin Pract 2006, 74:227-232.

13. Goudswaard AN, Stolk RP, Zuithoff P, Rutten GE: Patient characteristics do not predict poor glycaemic control in type 2 diabetes patients treated in primary care. Eur J Epidemiol 2004, 19:541-545.

14. Wallace TM, Matthews DR: Poor glycaemic control in type 2 diabetes: a conspiracy of disease, suboptimal therapy and attitude. QJM 2000, 93:369-374.

15. WHO: BMI classification.[http://apps.who.int/bmi/index.jsp? introPage=intro_3.html].

16. Vucic M, Petrovic S, Mesic R, Rocic B: An automated immunoturbidimetric assay for HbA1c determination. Clin Chem Lab Med 1999, 37:S199.

17. Yoshida D, Toyomura K, Fukumoto J, Ueda N, Ohnaka K, Adachi M, Takayanagi R, Kono S: Waist circumference, body mass index and glycated hemoglobin in Japanese men and women. Diabetes and Metabolic Syndrome: Clinical Research and Reviews 2001, 3:7-11.

18. Okosun IS, Dever GE: Abdominal obesity and ethnic differences in diabetes awareness, treatment, and glycemic control. Obes Res 2002, 10:1241-1250.

19. Blaha MJ, Gebretsadik T, Shintani A, Elasy TA: Waist circumference, not the metabolic syndrome, predicts glucose deterioration in type 2 diabetes. Obesity (Silver Spring) 2008, 16:869-874

20. Nagaretani H, Nakamura T, Funahashi T, Kotani K, Miyanaga M, Tokunaga K, Takahashi M, Nishizawa H, Kishida K, Kuriyama H, Hotta K, Yamashita S, Matsuzawa Y: Visceral fat is a major contributor for multiple risk factor clustering in Japanese men with impaired glucose tolerance. Diabetes Care 2001, 24:2127-2133.

21. Boyko EJ, Fujimoto WY, Leonetti DL, Newell-Morris L: Visceral adiposity and risk of type 2 diabetes: a prospective study among Japanese Americans. Diabetes Care 2000, 23:465-471.

22. Despres JP, Nadeau A, Tremblay A, Ferland M, Moorjani S, Lupien PJ, Theriault G, Pinault S, Bouchard C: Role of deep abdominal fat in the association between regional adipose tissue distribution and glucose tolerance in obese women. Diabetes 1989, 38:304-309.

23. Fox CS, Massaro JM, Hoffmann U, Pou KM, Maurovich-Horvat P, Liu CY, Vasan RS, Morabito JM, Meigs JB, Cupples LA, D'Agostino RB, O'Donnell CJ: Abdominal visceral and subcutaneous adipose tissue compartments: 
association with metabolic risk factors in the Framingham Heart Study. Circulation 2007, 116:39-48.

24. Scheen AJ: Abdominal adiposity: Early intervention and therapeutic options. Clin Cornerstone 2008, 9:20-27.

25. Davidson MB, Schriger DL: Effect of age and race/ethnicity on HbA1c levels in people without known diabetes mellitus: implications for the diagnosis of diabetes. Diabetes Res Clin Pract 2010, 87:415-21.

26. Gulliford MC, Ukoumunne OC: Determinants of glycated haemoglobin in the general population: associations with diet, alcohol and cigarette smoking. Eur J Clin Nutr 2001, 55:615-623.

27. Chan WB, Chan JC, Chow CC, Yeung VT, So WY, Li JK, Ko GT, Ma RC, Cockram CS: Glycaemic control in type 2 diabetes: the impact of body weight, beta-cell function and patient education. QJM 2000, 93:183-190.

28. Nilsson PM, Gudbjornsdottir S, Eliasson B, Cederholm J: Smoking is associated with increased $\mathrm{HbA} 1 \mathrm{c}$ values and microalbuminuria in patients with diabetes - data from the National Diabetes Register in Sweden. Diabetes Metab 2004, 30:261-268.

29. Bruce DG, Davis WA, Davis TM: Glycemic control in older subjects with type 2 diabetes mellitus in the Fremantle Diabetes Study. J Am Geriatr Soc 2000, 48:1449-1453.

doi:10.1186/1476-511X-9-83

Cite this article as: Ghazanfari et al.: Determinants of glycemic control in female diabetic patients: a study from Iran. Lipids in Health and Disease 2010 9:83.

\section{Submit your next manuscript to BioMed Central and take full advantage of:}

- Convenient online submission

- Thorough peer review

- No space constraints or color figure charges

- Immediate publication on acceptance

- Inclusion in PubMed, CAS, Scopus and Google Scholar

- Research which is freely available for redistribution

Submit your manuscript at www.biomedcentral.com/submit 